\title{
DIVERSIFIKASI DAN INOVASI PRODUK DARI IKAN NILA DAN LELE PADA PETAMBAK DI KECAMATAN SEI BINGAI SUMATERA UTARA
}

\author{
Khoiri $^{*}$, Teguh Febri Sudarma ${ }^{2}$, Anik Juli Dwi Astuti ${ }^{3}$ \\ ${ }^{1 *}$ Program Studi Pendidikan Teknik Otomotif, Fakultas Teknik, Universitas Negeri Medan, Medan \\ ${ }^{2}$ Program Studi Pendidikan Fisika, Fakultas Matematika dan Ilmu Pengetahuan Alam, Universitas Negeri Medan, \\ Medan \\ ${ }^{3}$ Program Studi Pendidikan Geografi, Fakultas Ilmu Sosial, Universitas Negeri Medan, Medan \\ *Penulis Korespondensi: khoiriko@yahoo.com
}

\begin{abstract}
Abstrak
Petani tambak lele dan nila di Desa Adi Mulio Kuwala Mencirin, Pasar V Dusun I Kecamatan Sei Bingai masih kesulitan dalam mengembangkan usahanya. Indikator dari hal ini karena laba yang di dapat petani rendah, hal itu disebabkan oleh tingginya harga pakan ikan yang harus dibeli di pabrikpabrik. Pemasaran yang dilakukan oleh petani tambak lele dan ikan nila di Desa Adi Mulio Kuwala Mencirin, Pasar V Dusun I Kecamatan Sei Bingai masih bersifat tradisional artinya hasil panennya langsung diambil oleh tengkulak. Melalui kegiatan Implementasi Mesin Pelet Ikan diharapkan dapat; (1) Menekan biaya operasional yang cukup tinggi, dengan membuat pakan ternak sendiri disertai dengan pembuatan mesin pellet pakan ternak untuk lele dan ikan nila, (2). Membantu proses pemasarannya, misalkan dengan memilih teknik pengemasan dan penyimpanan pakan yang baik dan (3) diversifikasi dan inovasi produk hasil budidayanya untuk menambah nilai jual. Capaian yang diperoleh. 1) Mesin sudah dapat berfungsi tetapi produk pelet masih seperti mie, belum berbentuk butiran. 2) Masyarakat mitra sudah dapat meramu bahan baku pembuatan pelet menjadi adonan pelet. Manajemen pengelolaan usaha masih perlu ditingkatkan.
\end{abstract}

Kata Kunci: Budidaya Ikan, Mesin Pelet Ikan, Petani Ikan.

\begin{abstract}
Farmers of catfish and indigo ponds in Adi Mulio Kuwala Mencirin Village, Pasar V Dusun I Sei Bingai Sub-district is still difficult to develop their business. The indicator of this is because the profit earned by farmers is low, it is due to the high price of fish feed that must be purchased in the factories. Marketing conducted by the farmers of the catfish and tilapia fish in Adi Mulio Kuwala Mencirin Village, Pasar V Dusun I Sei Bingai Subdistrict is still traditional means that the harvest is taken directly by the middleman. Through the Implementation of Fish Pellet Implementation is expected to; (1) Suppressing high operational costs, by making the animal feed itself accompanied by the manufacture of pellet feed machines for catfish and tilapia, (2). Helping the marketing process, for example by choosing good packaging techniques and storage of feed and (3) diversification and innovation of cultivated products to increase selling value. Achievements gained. 1) The machine can already function but the pellet product is still like noodles, not yet shaped granules. 2) Community partners have been able to assemble raw materials making pellets into dough pellets. Business management management still needs to be improved.
\end{abstract}

Keywords: Fish Cultivation, Fish Pellet Machine, Fish Farmer.

\section{PENDAHULUAN}

Desa Adi Mulio Kuwala Mencirin, Pasar V Dusun I Kecamatan Sei Bingai Kabupaten Langkat memiliki tempat pembudidayaan ikan yang luas. Di desa ini terdapat 86 orang petani tambak lele yang diketuai oleh bapak Djumain dengan jumlah kolam lele lebih dari 320 petak, sedangkan untuk petani tambak ikan nila terdiri dari 45 orang yang diketuai oleh bapak Sutarmin dengan jumlah kolam ikan nila di atas 85 kolam. Dengan beberapa jenis komoditi budaya perikanan yang di kembangkan di kecamatan
Sei Bingai menggunakan air tawar. Maka perkembangan yang terjadi pada proses pembudidayaan ini cukup baik dan hasilnya memuaskan. untuk mengembangakan budidaya perikanan tersebut 'ikan memerlukan makanan berbentuk pelet. Bagi makhluk hidup pakan merupakan syarat untuk hidup, tidak terkecuali ikan. Pakan digunakan untuk menghasilkan energi. Tubuh ikan dapat melakukan metabolisme dan bergerak. Tanpa energi,organ tubuh tidak dapat bergerak dan berfungsi. Selain sebagai penghasil energi, pakan 
juga berfungsi Memperbaikin sel yang rusak. Dengan begitu,bagian tubuh yang terluka bisa sembuh kembali. Pakan terdiri dari dua macam, yaitu pakan alami dan pakan buatan.

Proses pemberian pakan ikan dilakukan 3 kali sehari yaitu pukul 07.00 pagi, 17.00 dan 22.00. Pakan ikan tidak selalu 3 kali sehari bahkan sampai 4 kali sehari , dikarnakan asupan pakan alami yang terdapat pada kolam air kurang memenuhi asupan nutrisi pada ikan, Oleh sebab itu, perternakan perlu memperhatikan perbedaan kedua jenis pakan tersebut agar dapat menentukan saat yang tepat untuk mengunakan pakan alami atau pakan buatan. Pakan alami biasanya digunakan dalam bentuk hidup dan agak sulit mengembangkannya ,karena memerlukan perlakuan khusus sebelum pakan tersebut diberikan kepada ikan. Sedangkan pakan buatan dapat diartikan secara umum sebagai pakan yang diperlukan yang berasal dari olahan beberapa bahan pakan yang memenuhi nutrisi yang di perlukan. Pakan buatan banyak kita jumpai berbentuk pelet.

Secara keseluruhan di desa ini juga menghasilkan output ikan nila yang dihasilkan perhari bisa mencapai 3,5 ton, sedangkan lele menghasilkan 2 ton perhari. Tentu saja hasil tersebut dibarengi dengan pakan ikan nila dan lele yang cukup tinggi pula. Perhari, pakan yang mereka beli dari pabrik rata-rata menghabiskan 10 sak karung pakan dengan harga persaknya sekitar Rp. 215.000,-. Sehingga total perharinya, para petani tambak ini harus mengeluarkan uang sebesar Rp 2.150.000,untuk memberi makan lele dan ikan nilanya. Secara keseluruhan hampir $60 \%$ biaya operasional habis dipakai untuk membeli pakan lele dan ikan nila. Belum lagi kondisi ini ditambah dengan penjualan hasil produksi lele dan ikan nila yang dijual lewat tengkulak. Harga jual tentu saja bergantung pada tengkulak, bahkan ada beberapa tengkulak yang membayarnya tidak langsung cash, tapi masih menjanjikan beberapa hari lagi. Secara keseluruhan jika ditotal perbulan pendapatan yang diperoleh para petani tambak lele dan ikan nila ini hanya mencapai $20 \%$ dari total biaya keseluruhan. Pengeluaran terbesar adalah pada biaya pakan lele dan ikan nila.

Sehingga dari analisis situasi di atas, sangat penting untuk membuat pakan ternak sendiri sekaligus dengan pembuatan mesin pelletnya, dengan tujuan utama untuk mengurangi biaya pakan lele dan ikan nila yang hingga saat ini sangat bergantung pada pabrik. Lebih lanjut, program ini untuk memberdayakan dan alih teknologi sederhana dari Institusi ke para petani tambak agar dapat membuat pakan lele dan ikan nila sendiri. Dua mitra petani tambak yang ditentukan di atas, diharapkan dapat sebagai core awal yang akan menularkan ilmunya yang telah diberikan dalam kegiatan Abdimas ini nanti, kepada petani- petani tambak lainnya di desa dan kecamatan yang ada di Kabupaten Langkat.

\section{METODE PELAKSANAAN}

Kegiatan dilakukan di desa Adi Mulio Kecamatan Sei Bingai Kabupaten Langkat Provinsi
Sumatera Utara, yaitu pada petani tambak ikan nila dan lele. Berdasarkan permasalahan yang telah di kemukakan, maka dalam kegiatan Pengabdian ini metode pendekatan yang ditawarkan bagi realisasi kegiatan pengabdian ini adalah model pemberdayaan dengan langkah-langkah sebagai berikut : 1) Tahap Persiapan; 2) Tahap Assesment; 3) Tahap Perencanaan Alternatif Program atau Kegiatan; 4) Tahap Pemformulasian Rencana Aksi; 5) Tahap Pelaksanaan (Implementasi) Program atau Kegiatan; 6) Tahap Evaluasi; serta 7) Tahap Terminasi.

Pelaksanaan kegiatan pengabdian ini akan dilaksanakan sebagai upaya pemberdayaan kelompok petani tambak ikan di desa Adi Mulio Kuwala Mencirin, Pasar V Dusun I Kecamatan Sei Bingai Kabupaten Langkat dalam bidang pelatihan menitik beratkan kepada pengembangan Mesin Pencetak Pakan Ikan, Pembuatan Pakan Ikan dan Pembuatan Olahan Ikan. Metode pelaksanaan program yang akan dilakukan adalah : (1) Pelatihan manajemen usaha, (2) Pelatihan produksi, (3) Pelatihan administrasi dan (4) pendampingan. Semua metode ini merupakan satu kesatuan dari kegiatan pengabdian ini.

\section{DESKRIPSI PELAKSAAN KEGIATAN Tahap Persiapan}

Pelaksanaan kegiatan akan dikoordinasikan dengan LPM-UNIMED dan tim mitra dan Instansi yang terkait seperti pengurusan surat ijin, penyusunan jadwal kegiatan dan persiapan pembuatan Mesin Pencetak Pakan Ikan, Pembuatan Pakan Ikan dan Pembuatan Olahan Ikan yang akan diberikan kepada Tim Mitra. Tahapan persiapan untuk pembuatan Mesin Pembuat Pakan Ikan adalah meliputi perancangan yang sudah dianalisa seluruh aspek yang diperlukan untuk meningkatkan produk yang berkualitas, kapasitas effisien dan tentunya harga alat yang dapat dijangkau oleh UKM.

Pembuatan alat akan dilaksanakan di Workshop Teknik Mesin FT Unimed yang telah mempunyai sarana dan prasarana yang mendukung untuk kegiatan ini.

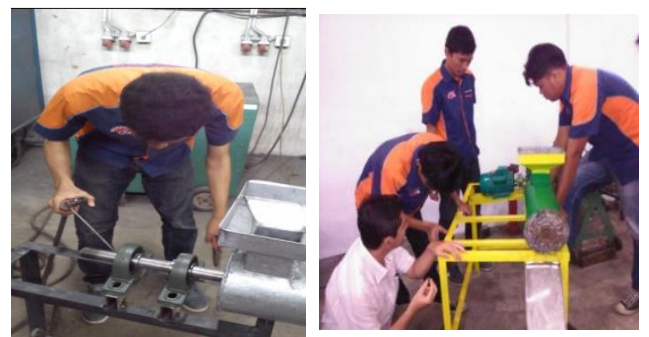

Gambar 1. Pembuatan Mesin Pelet Ikan

\section{Tahap Pelaksanaan}

a) Motivasi Usaha

Memberikan pelatihan dalam bentuk motivasi wirausaha dan berbagi pengalaman dengan narasumber yang diundang adalah wirausahawan yang telah berhasil dalam bidang pengelolahan gula semut. Kegiatan ini akan diarahkan untuk mengubah cara berfikir (mindset) bagi mitra usaha sehingga 
dapat menumbuhkan semangat untuk lebih maju dalam mengembangkan usaha. Program ini dirancang dalam suasana diskusi interaktif untuk menampung segala aspirasi, permasalahan dan potensi usaha yang dikembangkan oleh mitra maupun kelompok usaha pengelolahan gula lainnya.

\section{b) Pelatihan Manajemen Usaha}

Kegiatan ini adalah memberikan wawasan tentang strategi bagaiamana merintis dan mengembangkan usaha bagi para pengusaha petani tambak ikan lele dan nila berkaitan dengan jenis usaha yang sedang dijalaninya termasuk pengembangan olahan ikan lele dan ikan nila.

\section{c) Pelatihan Penggunaan Mesin Pencetak Pakan Ikan, Pembuatan Pakan Ikan dan Pembuatan Olahan Ikan}

Memberikan pelatihan cara pengoperasian, produksi dan pemeliharaan Alat. Peserta pelatihan adalah para pengrajin didesa yang dijadikan Mitra Pengabdian yang akan memakai dan mengoperasikan peralatan yang di bimbing sampai Tim Mitra mengetahui dengan baik secara detail Mesin Pembuat Pakan Ika, pembuatan pakan ikan dan pembauatan olahan ikan oleh TIM Pakar.

\section{Pendampingan}

Program pendampingan dalam kegiatan yang akan dilakukan bertujuan adalah untuk mendampingi Tim Mitra untuk meningkatkan dan mengembangkan Usaha yang di kelolanya menjadi lebih baik.

\section{a) Pembinaan dan Pemberdayaan UKM Mitra}

Langkah pembinaan dan pemberdayaan UKM Mitra untuk menyiapkan kelompok UKM mitra yang handal dalam menjalankan aktivitas kegiatan adalah :

- Menyiapkan bahan penyuluhan penatanan untuk pendamping Tim Mitra

- Menyiapkan pendamping dari tim pakar perguruan tinggi.

- Pembinaan kelompok oleh pendamping dan instansi terkait.

- Merealisasi program aksi dengan cara kemitraan.

- Memonitoring dan evaluasi kegiatan usaha yang dilakukan.

\section{b) Evaluasi}

Evaluasi dilakukan secara bertahap yaitu :

- Tahap awal adalah mengukur tingkat keberhasilan dari motivasi yang telah diberikan

- Tahap proses kegiatan adalah mengetahui kemampuan Tim Mitra mengimplimentasikan seluruh materi pelatihan yang telah diberikan oleh tim pakar.

- Tahap akhir adalah melihat keberhasilan dari kegiatan yang telah dilaksanakan yang diindikasikan berproduksinya Mesin Pencetak Mie, Pengolahan ikan lele dan ikan nila dan hasil produksinya lebih baik dari sebelumnya.
Tahap Pemantauan

Tahap pemantauan ini dilakukan setelah kegiatan selesai apakah berjalan sesuai dengan yang diharapkan.

\section{HASIL DAN PEMBAHASAN}

\section{a) Mesin Pembuat Pelet Ikan}

Penerapan teknologi dalam penyelesaian permasalahan petani tambak ikan adalah implementasi mesin pembuat pakan ikan (pelet). Mesin pelet bekerja secara mekanis dan esin yang dihasilkan mudah dioprasikan serta mudah dalam perawatan nantinya. Mesin pelet ikan yang diimplementasikan merupakan rancangan Fakultas Teknik Mesin Universitas Negeri Medan. Mesin pelet ikan digerakan dengan motor listrik, sehingga ketergantungan akan bensin yang susah didapat di daerah tambak bisa dihindari.

\section{b) Pelatihan Pembuatan Pakan Ikan}

Pelatihan pembuatan pakan ikan buatan dilakukan dengan beberapa tahapan, antara lain :

1. Penghalusan bahan baku Sebelum dilakukan penghalusan, bahan baku seperti bubuk ikan, jagung dan kedelai dijemur terlebih dahulu untuk mengurangi kadar air yang dikandung bahan. Penjemuran ikan cirik dilakukan selama lebih kurang empat hari sehingga ikan betulbetul kering.. Hal yang sama juga dilakukan untuk bahan baku jagung dan kacang kedelai. Setiap bahan digiling menggunakan mesin penepung. Setelah digiling, setiap bahan baku diayak agar ukurannya seragam. Simpan dalam wadah plastik dan diberi nama/label yang jelas.

2. Penimbangan bahan baku

Proses pembuatan pakan ikan buatan, diperlukan bahan-bahan seperti jagung, dedak, tepung ikan, dan tepung terigu, tepung tapioka, minyak ikan dan yeast.

3. Pencampuran bahan baku

Pencampuran bahan dilakukan dengan cara yang sedikit dahulu, baru kemudian yang banyak. Urutan pencampuran adalah : yest, tepung tapioka, tepung gandum, tepung kedelai, tepung jagung, tepung ikan, dan dedak halus. Pencampuran dilakukan secara manual.

4. Pencetakan pakan

Proses pencetakan pakan dilakukan menggunakan mesin pakan hasil fabrikasi. Tepung tapioka berfungsi sebagai bahan perekat agar teksturn pakan kompak dan memiliki ketahanan dalam air untuk beberapa lama. Tapioka di masak dengan air, sehingga berbentuk sepeti lem, kemudian sedikit-sedikit dicampurkan ke bahan-bahan utama. Masukkan ke dalam mesin pencetak, lalu dicetak dengan ukuran yang diinginkan. Gambar 2 memperlihatkan proses pencetakan pakan menggunakan mesin pelet ikan ini. 

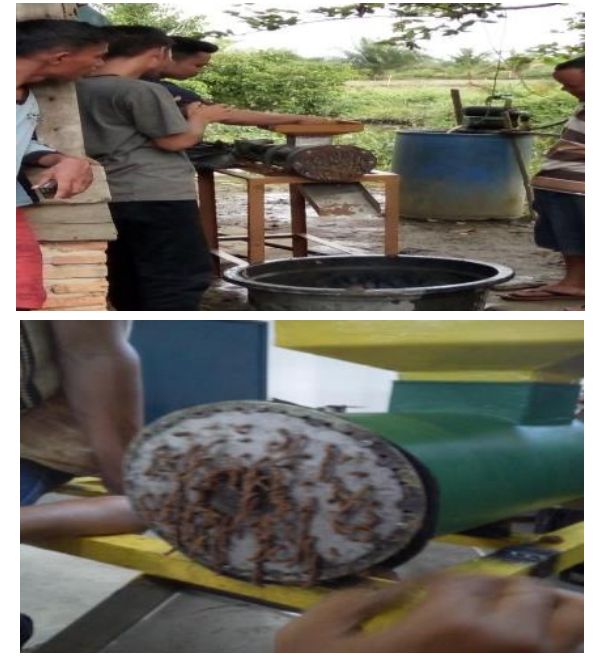

Gambar 2. Pelatihan Pembuatan Pelet Ikan

5. Pengeringan pakan

Pakan yang telah dicetak kemudian dikeringkan di bawah matahari. Setiap 2 jam sekali pakan (pelet) dilakukan pembalikan. Apabila kadar air pelet kurang lebih 10\% yang ditandai dengan mudahnya pelet dipatahkan tapi tidak hancur, selanjutnya pelet diangkat dan dikemas.

Selain dengan bahan yang dibeli Peternak lele dan ikan nila juga diajari teknik fermentasi kotoran sapi untuk menjadi bahan pakan lele dan ikan nila sebagai bahan tembahan.

\section{c) Perbandiangan harga Pakan}

Harga pakan pellet ikan yang telah diproduksi oleh peternak ikan dan dipasarkan kepada anggota kelompok dapat ditekan menjadi $\mathrm{Rp} 6.500 / \mathrm{kg}$ jauh dibawah harga pakan pabrik yang mencapai $\mathrm{Rp}$. $9.000 / \mathrm{kg}$.

\section{d) Kendala yang masih dihadapi}

- Pellet ikan yang telah diproduksi masih 'tenggelam' dan kualitas proteinnya belum sebaik pakan pellet dari pabrik, sehingga sebagian peternak lele masih belum 'yakin' dan kurang menerima pellet buatan kelompok. Sebagian peternak karena 'bujukan' tengkulak pakan, kembali menggunakan pakan pellet dari pabrik dengan alasan lebih mudah (tidak merepotkan), mengapung, kadar protein cukup tinggi, terbukti dapat memperbesar lele yang dipelihara.

- Kondisi iklim yang kurang kondusif (ekstrim) sangat berpengaruh dalam budidaya ikan, yaitu munculnya kasus tingkat kematian yang cukup tinggi, khususnya pada usia muda dan pertumbuhan menjadi lebih lambat, karena nafsu makan menjadi sangat berkurang akibat perubahan cuaca yang ekstrim.

\section{KESIMPULAN}

1. Pengetahuan dan ketrampilan produksi pakan pellet ikan secara mandiri, telah mampu menurunkan biaya produksi atau pengadaan pakan ikan yang cukup signifikan.

- Mitra elah diperkenalkan teknologi mesin pellet untuk memproduksi pakan pellet ikan lele secara mandiri dari ramuan pakan pellet yang diolah sendiri.

- Budidaya lele dan nila sangat bergantung dengan faktor lingkungan, cuaca atau iklim, penyakit, dan kualitas bibit. Gangguan oleh cuaca yang ekstrim, penyakit dan kualitas bibit masih menjadi masalah mitra.

\section{DAFTAR PUSTAKA}

Adrian Syahputra. (2010). Rancang Bangun Alat Pembuat Pakan Ikan Mas Dan Ikan Lele Bentuk Pellet.

Afrianto, E dan P. E., Liviawaty. (2005). Pakan Ikan. Yogyakarta: Kanisius.

Anonim, 2013e. Adonan Bakso. http://id.wikipedia.org/wiki/Adonan Bakso. Akses 10 Oktober 2013, Sidoarjo.

Daniel Pratama dkk, 2015, Proses pembuatan dan pengujian mesin pembuat pakan ikan, TA, Jurusan Teknik Mesn FT Unimed.

Mudjiman, A., 1996. Makanan Ikan. Penebar Swaday a, Jakarta.

Sani, R.A ( 2013),. Pembinaan Masyarakat Berbasis Iptek, CitaPustaka Media Perintis, Medan. 